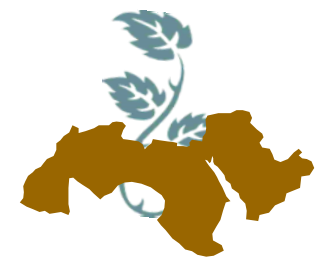

Arab Univ.

J. Agric. Sci., Ain Shams Univ., Cairo, 26(1), 313-325, 2018

\title{
COMPLETION OF LABEL INFORMATION AND PHYSICO-CHEMICAL PROPERTIES OF COMMERCIAL PESTICIDE SAMPLES TRADED IN EGYPTIAN MARKETS
}

\author{
Dalia T. Abdelhameed; T.A. Mashtoly and M.S. El-Zemaity \\ Plant Protection Dept., Fac. of Agric., Ain Shams Univ., Cairo, Egypt
}

Keywords: Formulations, Label, Specifications, Substandard, Counterfeit, Surveillance

\section{ABSTRACT}

The current study was carried out to check the completion of label information and determine the physico- chemical properties of commercial pesticides samples traded in the Egyptian markets. Twenty-nine market samples were collected during the years 2015 and 2016 for commercial formulations produced by different manufacturers from pesticide shops in four governorates (Cairo, Giza, Qaluobia and Sharqia). The collected samples included 18 preparations in the form of Emulsifiable Concentrates (EC), 11 in the form wettable powder (WP). Physico- chemical properties were determined for each formulation according to international standard methods (CIPAC, 2003) through tests of $\mathrm{pH}$ value, Persistent Foam, Emulsion Stability, Suspencibility and Wettability. The obtained results showed that although the label data was complete for many of the packages, some information found be missing. The missing information was related to directions for use $(4 \%)$, safety precautions and first aid (7\%), anti-dote $(12 \%)$, hazard category (6\%), Pre-Harvest Interval, (PHI) (17\%), registration number (13\%) and Batch number (18\%). Regarding physico- chemical properties, the obtained data indicated that there was a difference in the percentage of the foam layer for the tested formulations of chlorprifos-ethyl (6 preparations) (Tafaban 48\%EC, Pyrifos El-Nasr 48\% EC, Pestiban 48\% EC, Pyriban-A 48\% EC, Chlorfan $48 \%$ EC and Chlorzan 48\% EC). These preparations were in accordance with international standards in terms of emulsion stability after half an hour, while the mismatching samples showed that the formed layer exceeded the standard volume after two hours of maximum limits, and failed to test emulsion stability after 24.5 hours, as well as in the free oil layer formed at the same time. The results of the emulsion stability tests showed four other tested formulations, namely, lambda chalothrin (Fly Free 5\% EC), chlorpyrifos - methyl (Pyrodan $50 \% \mathrm{EC}$ ), and two different formulations for malathion (Agrothion 57\% EC and Malason Extra $57 \% \mathrm{EC}$ ), all of which conform to standard specifications in terms of level of foam layer, as well as complete emulsification after half an hour. The cream layer after half an hour was identical. However, the difference and mismatch in three formulations appeared after two hours of emulsification, where the percentage of the cream layer exceeded the allowed limits, and the free oil layer was not conforming to specifications, (after two hours or 24.5 hours). Also, the tested preparations of abamectin (Demectin 1.8\% EC and Gold 1.8\% EC) and emamectin benzoate (Basha 1.9\% EC and Excellent $1.9 \% \mathrm{EC}$ ) have been successful in the tests of Persistent Foam, Emulsion stability (cream layer and free oil layer formed after half an hour and two hours as well as 24.5 hours). Comparing the efficiency of emulsification among other EC formulations including fenitrothion (Sumithion $50 \%$ EC), diazinon (Diazinox 60\% EC) and profenofos (Sylian $72 \%$ EC and Teleton $72 \%$ EC) conformed to specifications in terms of level of foam layer. However, both Sumithion and Diazinox failed to stabilize, forming a creamy layer that exceeded the standard the maximum limit after two hours. For WP formulations, some have successfully passed the suspensibility test, while other formulations, including preparations of Bacillus thuringensis bacteria (Agerin 6.5\% WP, Dipel 2X 6.4\% WP and Protecto $9.4 \% \mathrm{WP}$ ). have not been successful. These results confirm the importance of developing monitoring and surveillance activities for pesti-

(Received 19 July, 2017) 
cides formulations traded on the market, and to develop special means for checking the quality of products and detecting products that are counterfeit or non-conforming to the declared specifications or National and International standards.

\section{INTRODUCTION}

Successful control of agricultural pests and pathogens is based on effective pesticides of acceptable quality that do not cause undesirable adverse effects when used at recommended rates. In fact, the use of non-standard products (fake, counterfeit, adulterated pesticides) can have serious adverse effects on human health and the environment, and the use of these products may result in unsatisfactory or sufficient results towards the target pests. Specifications and the strength or purity of such pesticides could be below the purported or professed standard of quality as expressed in its labeling, the contents of the package or container of pesticide do not meet their purported standard of quality in any other manner and the contents of the package or container represented to be a pesticide are not definitely effective for the purpose for which recommended (Legislative Counsel Committee, 2016 a\&b). Also, the chemical composition of counterfeit pesticides has not been studied, and therefore even a partial change in the physicochemical properties of the chemical components might increase its toxic effects. Substandard pesticides can also cause long-term contamination of soil, groundwater and surface water, which can also lead to transboundary impacts. In addition to being a threat to human health and to the environment, counterfeit and contraband products pose a risk to the economic activity of enterprises involved in the entire food production chain: losses due to confiscation of pesticides or products that do not meet quality standards, reputational risks (Malkov et al 2015).

The problem of disturbing and traded substandard / counterfeit, poorly labelled, and highly toxic pesticide products is likely to be widespread (Matthews et al 2010 and Rother, 2010). Several reports and estimates, particularly for the Food and Agriculture Organization of the United Nations (FAO) and the World Health Organization (WHO), indicate that as of the first decade of the current century, such pesticides have increased in the markets of developing countries, accounting for about 30\%, and that they did not meet internationally accepted quality standards (Malkov et al 2015). Regarding the significance of the problem in
Egypt, the Agricultural Pesticides Committee estimates according to preliminary studies in 2015 that the size of pesticides (fraudulent and smuggled inside Egypt), to be $18-20 \%$ of the total pesticides consumed. In 2016 the Committee reported that the size of the adulterated pesticides in Egypt declined to 14\% (Alnuwbaa, 2016; Hamid, 2016 and Salem Amira, 2016).

For this situation, both FAO and WHO developed and published standard specifications for technical substances and formulations, with the aim of being used as International reference standards on which to judge commercial products of pesticides traded on the market. JMPS (2010), developed measures of pesticide specifications as a result of focusing efforts in recent years and cooperates with other organizations in establishing technical specifications for active ingredients and formulations. The published specifications are developed with the basic objective of promoting, as far as practicable, the manufacture, distribution and use of pesticides that meet basic quality requirements. The specifications encompass the physical appearance of the material, its content of active ingredient and any relevant impurities, and its physical and chemical properties, and stability in storage. These specifications are intended for quality assurance and risk management. In general, specifications could be used as part of a contract of sale, so that a buyer may purchase a pesticide with some guarantee of the quality expected; and by the competent authority to check that the quality of the formulation on the market is the same as that registered (FAO/WHO, 2014). FAO/WHO specifications are intended to enhance confidence in the purchase and use of pesticides and thus to contribute to human and environmental safety, as well as to more sustainable agricultural production and improved public health FAO/WHO (2011) \& WHO (2015). Of course, the responsible authorities in the country encourage factories and plants working in the field of pesticides production and formulations to work and take the necessary measures to control the quality of their products, and take such specifications for general purposes to control pesticides traded in the markets.

Considering that the specifications encompass the: physical appearance of the product, content of active ingredient, relevant impurities, physical and chemical properties, package conditions and stability in storage. In addition such specifications are intended for quality assurance and to check that the quality of the formulation on the market is the same as that registered. So, the objective of the 


\section{Completion of label information and physico-chemical properties of commercial pesticide samples traded in Egyptian markets}

present work is to investigate completion of information of labels of commercial pesticide packages traded through licensed pesticide shops, as well as determination of physico-chemical properties of commercial pesticide formulation samples traded in Egyptian markets.

\section{MATERIALS AND METHODS}

\section{Completion of label accompanying pesticide packages}

A standard pesticide label was designed to cover all data and the required information/data reported by Agricultural Pesticide Committee, Egyptian Ministry of Agriculture and Land Reclamation. Ninety different samples of commercial pesticide products traded in Egyptian market (90 packages) were collected from licensed pesticide shops (6 shops) located in different areas in Great Cairo .Validity of label condition accompanying of each package was carried out by comparing and matching of involved information and the standard label, and all differences about them was recorded. Percentage of completion/ fulfilment of label information/ data were calculated.

\section{Physico-chemical properties of the tested formulations}

Samples of two different types of formulations: Emulsifiable Concentrate (EC, 18 samples) and
Wettable Powder (WP, 11 samples) were collected from pesticide traders. Formulations, numbers of samples and producers are shown in Tables (1). The collected samples were varied due to the availability in the pesticide market at the time of doing the experiments. Also, the variation in active ingredients of samples was related to the differences between manufactures in their number of registered formulation. The total collected samples was 29 formulations which included 6 formulations of chlorpyrifos (Tafaban 48\%EC, Pyrifos El-Nasr 48\% EC, Pestiban 48\% EC, Pyriban-A 48\% EC, Chlorfan 48\% EC and Chlorzan 48\% EC), 2 formulations of malathion (Agrothion 57\% EC and Malason Extra $57 \%$ EC), 2 formulations of abamectin (Demectin 1.8\% EC and Gold 1.8\% EC), 2 formulations of emamectin benzoate (Basha $1.9 \% \mathrm{EC}$ and Excellent 1.9\% EC), 2 formulations of profenofos (Sylian $72 \%$ EC and Teleton $72 \%$ EC), 2 formulations of carbendazim (Kemazed 50\% WP and Pendazin 50\% WP), 2 formulations of mancozeb (Anadol 80\% WP and Dicozeb 80\% WP), 3 formulations of Bacillus thuringiensis (Agerin 6.5\% WP, Dipel 2X 6.4\% WP and Protecto 9.4\%WP). and one formulation for lambda cyhalothrin (Fly Free 5\%EC), chlorpyrifos-methyl (Pyrodan 50\% EC), fenitrothion (Sumithion 50\% EC), diazinon (Diazinox 60\% EC), thiram (No- Blight 50\% WP), deltamethrin (Dikathrin 5\% WP), diflubenzuron (Difix 25\% WP) and thiophanate- methyl (Hesta $70 \%$ WP).

Table 1. Numbers, type of formulations and manufacture of collected samples for physico - chemical properties tests

\begin{tabular}{|c|c|c|c|}
\hline Manufacture & EC & WP & Total \\
\hline $\begin{array}{l}\text { El- Helb Pesticides \& Chemicals Company } \\
\text { (Basha, Gold, Hesta, Pyriban -A and Tafaban) }\end{array}$ & 4 & 1 & 5 \\
\hline $\begin{array}{l}\text { El- Nasr Company for Intermediate Chemicals } \\
\text { ( Pyrifos -El-Nasr) }\end{array}$ & 1 & - & 1 \\
\hline $\begin{array}{l}\text { The National Company for Fertilizers \& Chemicals (Agrochem) } \\
\text { ( Agrothion, Demectin, Dicozeb, Pendazin Pestiban, Pyrodan, Teleton) }\end{array}$ & 5 & 2 & 7 \\
\hline $\begin{array}{l}\text { Kafr El Zayat for Pesticides \& Chemicals Company } \\
\text { (Anadol, Chlorfan, Chlorzan, Diazinox, Difix, Dikathrin, Excellent, Fly } \\
\text { Free, Kemazed, Malason, No- Blight, Protecto Sumithion,, Sylian,) }\end{array}$ & 8 & 6 & 14 \\
\hline $\begin{array}{l}\text { Genetic Engineering \& Biotechnology Research Institute } \\
\text { ( Agerin) }\end{array}$ & - & 1 & 1 \\
\hline $\begin{array}{l}\text { Valent Bioscience Corporation,USA } \\
\text { ( Dipel } 2 X \text { ) }\end{array}$ & - & 1 & 1 \\
\hline Total & 18 & 11 & 29 \\
\hline
\end{tabular}


Each formulation was tested to determine the physicochemical properties of the product by using CIPAC, 2003 methods as follows:

\section{A- Emulsifiable Concentrates (EC)}

1- pH- Value Test (MT75, CIPAC F., 2003), pHvalue was determined using Schott Handy $\mathrm{Lab} \mathrm{pH}$ meter.

2- Persistent Foam Test (MT 47.1, CIPAC F. 2003). The amount of formulation to be taken for making a concentration which emulate the $200 \mathrm{ml}$ spraying solution that used in the fields was weighted and added to $180 \mathrm{ml}$ of standard water into $250 \mathrm{ml}$ measuring cylinder. Cylinder was stoppered and inverted 30 times and then placed upright on the bench in the laboratory and immediately the volume of foam was recorded after $1 \mathrm{~min}$.

3- Emulsion Stability Test (according CIPAC MT36.3 (2003), Hard water was prepared by dissolving $0.304 \mathrm{gm}$ of anhydrous calcium chloride and $0.139 \mathrm{gm}$ of magnesium chloride hexahydrate in sterilized distilled water and made up to one liter. This provides total hardness equivalent to 342 ppm of calcium carbonate. Soft water was prepared by mixing one volume of hard water with five volumes of sterilized distilled water to provide water hardness of $57 \mathrm{ppm}$. Emulsion stability test was carried out using $100 \mathrm{ml}$ - glass graduated stopper cylinders which were filled with freshly prepared hard water and soft water up to level $95 \mathrm{ml}$ volume, calculated EC pesticide formulations required to prepare $100 \mathrm{ml}$ was added. The cylinders were inverted at $180 \pm 1^{\circ} \mathrm{C}$ at the 1 rate of complete cycle per $2 \mathrm{sec}, 30$ complete cycles were done after 30 min, any separation or precipitation at either top or bottom of the cylinder were recorded and it was used as an indicator of emulsion stability.

\section{B- Wettable Powders (WP)}

1-Wettability Test (MT 15.2 Hand book F) About $100 \pm 1 \mathrm{ml}$ of standard water was poured into a beaker and then $5 \mathrm{gm} \pm 0.1 \mathrm{~g}$ of a representative sample of the wettable powder pesticide formulations was added at once, by dropping it on the water from a position level with the rim of the beaker without agitation. The time taken was recorded to the nearest second until it becomes completely wetted.
2- Suspencibility Test (MT15- CIPAC F 2003). (Known amount of wettable powder pesticide formulations $(6.25 \mathrm{gm})$ was weighted and added to $250 \mathrm{ml}$ of standard water. Cylinder was stoppered and inverted 30 times at $180 \pm 1^{\circ} \mathrm{C}$ and backed again. The cylinder was placed in water bath at constant temperature $30 \pm 1 \mathrm{C}^{\circ}$ for about $30 \mathrm{~min}$ in an upright position free from vibration or direct sun light. After the specified time $225 \mathrm{ml}$ which is $9 / 10^{\text {th }}$ of the whole suspension was drawn off using suction tube in about 10-15 sec. and the remained $1 / 10^{\text {th }}$ was transferred quantitively using distilled water on a filter paper then the filter paper was dried and reweighted.

Percentage of suspensibility was calculated using the following equation:

\section{Suspensibility $=10 / 9 \times 100(C-Q) / C=111(C-Q) / C \%$}

\section{Where:}

$A=$ the amount of active ingredient determined in the sample before or after a accelerated storage as may be appropriate (\%),

$\mathrm{B}=$ the mass of the sample taken $(\mathrm{gm})$,

$\mathrm{C}=$ the mass of active ingredient in sample actually taken $=a b / 100$ (gm),

$\mathrm{Q}=$ the mass of active ingredient in the $25 \mathrm{ml}$ remaining in the cylinder (gm).

3-Persistent Foam Test (MT 47.1 CIPAC Handbook F). During the suspensibility test, the persistence foam was measured after the inversion of 30 times. All the tested wettable powder pesticide formulations were subjected to measure the persistence foam test.

\section{RESULTS AND DISCUSSION}

A- Completion of label accompanying pesticide packages traded in Egyptian markets

The data in Table (2) showed that the labels of $100 \%$ of the tested packages contain the commercial name, the common name, the chemical composition and the percentage of the active ingredient, while $1 \%$ of the packages do not contain the pictogram and the color of the packaging indicating hazard categories. About $4 \%$ of the investigated labels do not contain information about use, and about $7 \%$ do not contain safety precautions and first aid. Some of labels does not contain anti-dote $(12 \%)$, and $6 \%$ of the labels does not contain 

pesticide samples traded in Egyptian markets

Table 2. Completion \% of label information/data of the investigated pesticide packages traded in Egyptian markets

\begin{tabular}{|c|c|c|c|c|}
\hline \multirow{2}{*}{\multicolumn{2}{|c|}{ Required data }} & \multicolumn{2}{|c|}{ Included Information } & \multirow{2}{*}{$\%$ Completion * } \\
\hline & & Present & Absent & \\
\hline 1 & Brand (trade ) name & 90 & 0 & 100.00 \\
\hline 2 & Concentration & 90 & 0 & 100.00 \\
\hline 3 & Formulation type & 90 & 0 & 100.00 \\
\hline 4 & Chemical group & 90 & 0 & 100.00 \\
\hline 5 & Active ingredient (Common name) & 90 & 0 & 100.00 \\
\hline 6 & Surface active agent+ Solvent & 90 & 0 & 100.00 \\
\hline 7 & Ingredient statement & 90 & 0 & 100.00 \\
\hline 8 & Pictograms and color of hazard category & 89 & 1 & 98.89 \\
\hline 9 & Information for use & 86 & 4 & 95.56 \\
\hline 10 & Use & 86 & 4 & 95.56 \\
\hline 11 & Safety period ( Pre-harvest intervals) & 75 & 15 & 83.34 \\
\hline 12 & Warranty & 85 & 5 & 94.45 \\
\hline 13 & Production date & 90 & 0 & 100.00 \\
\hline 14 & Expiration date & 90 & 0 & 100.00 \\
\hline 15 & Lot No. & 50 & 40 & 55.56 \\
\hline 16 & Registration No. & 79 & 11 & 87.78 \\
\hline 17 & Package capacity & 90 & 0 & 100.00 \\
\hline 18 & Hazard statement & 85 & 5 & 94.45 \\
\hline 19 & Antidote & 80 & 10 & 88.89 \\
\hline 20 & Storage method and conditions & 81 & 9 & 90.00 \\
\hline 21 & Safety precautions and First aids & 84 & 6 & 93.34 \\
\hline 22 & Disposal of containers & 76 & 14 & 84.45 \\
\hline 23 & Name and address of manufacturers & 90 & 0 & 100.00 \\
\hline 24 & Name and address of imported Co. & 90 & 0 & 100.00 \\
\hline 25 & Batch No. & 74 & 16 & 82.23 \\
\hline
\end{tabular}

* Based on the total number of the examined labels (90 packages).

information deal with the compound hazard. The labels did not mention the Pre-Harvest Interval (PHI) revealed $17 \%$. Whereas, about $13 \%$ of the labels did not contain the local registration number, and about $18 \%$ did not mention the Batch number. Although, there are a lot of information on labels that are required by the Agricultural Pesticide Committee and some were present in investigated labels, some others not found. The obtained data in agreement with El-Zemaity (2002) \& EIZemaity and Mohamed (2005) they reported that absences of certain information on labels of different pesticides packages. Regarding the importance and the required information on the labels. Rizk (2006) indicated that the product label must be approved by authorities to ensure that data printed on label is in accordance with Local/ National and International regulations. Label informations should be in Arabic. Pesticide label should be in compliance with FAO guidelines on good labeling practices and with $\mathrm{WHO}$ recommended classification of pesticide by hazard. A color coding system and the use of pictograms are incorporated in pesticide labels, and will be include in the future better handling and safety measures. On the other hand, some investigations reported absence of certain basic information from the labels accompanied the commercial pesticide packages such as Dinham (2007) who reported that an investigation carried out in China, Indonesia and Pakistan re- 
vealed that a comparison with the detail of PPE specified on labels of Gramoxone products of a similar formulation in the USA or Germany found that products in this survey had less detailed instructions, suggesting double standard between the requirements in developed and developing countries.

\section{B- Physico-chemical properties of the tested formulations}

\section{1- Emulsifiable Concentrates (EC)}

Results of the 6 tested EC formulations of chlorpyrifos were shown to differ in the percentage of the foam layer (Table 3). The pyriban-A product from El-Helb Pesticides and Chemicals Company (New Damietta Free Zone) and Pestiban from the National Agrochemical Company (Agrochem) are lower in the percentage of the presence of foams, followed by a Tafaban product produced by ElHelp Pesticides and then by Pyrifos El-Nasr, produced by NSC, then Pyrifos -El-Nasr and Chlorzan produced by El- Nasr Co. and KZ, respectively. The obtained results showed that all chlorpyrifosethyl formulations were in compliance with international standards in terms of emulsifying stability after half an hour, while non-conformance with the international standards appeared in six formulations, as a result of exceeding the cream layer formed after two hours of maximum limits. On the other hand, all formulations of chlorpyriphos- ethyl failed to test emulsion stability after 24.5 hours, as well as in the free oil layer formed at the same time. Table (4) show the results of the test of emulsification stability and the formation of the foam layer for other different EC preparations includes: Agrothion 57\%, Malason Extra 57\%, Sylian $72 \%$, Teleton $72 \%$, Sumithion $50 \%$, Diazinox $60 \%$, Fly Free 5\% and Pyrodan 50\%). The obtained data showed that they all conform to the international standards in the level of the foam layer, as well as the complete emulsification after half an hour. After half an hour was also identical, but the difference and mismatch appeared in three of formulations after two hours of emulsification, where the proportion of the layer of creams exceeded the limits set internationally for each type of formulation, and the layer of free oil was not conform to specifications either after 2 hours or 24.5 hours. Data in Table (5) show the results of the test of two different formulations of abamectin and two different preparations of the emamectin benzoate produced by the $\mathrm{Na}$ tional Company for Agrochemicals and Investment,
El-Helb Pesticides and Chemicals, respectively, the samples conform to international standards in terms of level of foam and the layer of cream and oil free layer formed after half an hour, two hours, and 24.5 hours. Comparing the efficiency of emulsification among other emulsifying formulations including Sumithion, Diazinox, Sylian, and Teleton, it was found that the four formulations met the specifications in terms of level of foam layer, but both of Sumithion and Diazinox were failed in stability test, where it formed a layer of cream exceeded the standard maximum after two hours. This problem did not appear in the Sylian and Teleton, where they were in accordance with standard specifications.

\section{2-Wettable Powders (WP)}

All the tested WP formulations underwent both the Wettability and Persistent Foam Tests. Regarding the suspensibility data in Table (6) show the results of eleven WP formulations (8 insecticides and fungicides chemically synthesized +3 formulations for biopesticides prepared from Bacillus thingness bacteria). The obtained data showed that six of the tested chemical pesticides successfully passed the suspensibility test as their attachment ratios were higher than the minimum attachment limits specified in the specifications. The remaining five pesticides ( 2 chemicals +3 biopesticides) were not identical and their attachment ratios were below international standards.

From the obtained results, it could be concluded that the tested pesticide formulations were not passing the requirements of certain tests of the two types of formulations. Some of the EC formulations were failed to test emulsion stability after 2 and 24.5 hours of maximum limits, as well as in the free oil layer formed at 24.5 hours. Regarding WP formulations, some of them were not passing through the sieve in suspensibility test. This may be due to the efficiency of the surfactants and other substances. Moreover, the practices of handling and storage of pesticides formulations may affect and play role on these properties (FAO/WHO, 2002 \& El-Zemaity and Mohamed, 2005). So, pesticide formulations must be checked by the manufacturers in cooperation with responsible authorities before and during marketing under the actual conditions of storage to confirm the required specifications before purchase and application by pesticide users. The obtained data emphasize the importance of developing monitoring and surveillance 

pesticide samples traded in Egyptian markets 

pesticide samples traded in Egyptian markets

Table 5. Physico- chemical properties four different Abamectin and Emamectin benzoate EC formulations

\begin{tabular}{|c|c|c|c|c|c|}
\hline \multicolumn{4}{|c|}{ Abamectin } & \multicolumn{2}{|c|}{ Emamectin benzoate } \\
\hline $\begin{array}{c}\text { Tests } \\
\text { (Parameters) }\end{array}$ & Time & $\begin{array}{c}\text { Demictin } \\
1.8 \% \text { EC } \\
(\mathrm{ML})\end{array}$ & $\begin{array}{c}\text { Gold } \\
1.8 \% E C \\
\text { (ML) }\end{array}$ & $\begin{array}{c}\text { Excellent } \\
1.9 \% \mathrm{EC} \\
(\mathrm{ML})\end{array}$ & $\begin{array}{c}\text { Basha } \\
1.9 \% \text { EC } \\
(\mathrm{ML})\end{array}$ \\
\hline Persistence foam & $1 \mathrm{~min}$ & $\begin{array}{c}15 \mathrm{ml}(+) \\
(20 \mathrm{ml})\end{array}$ & $\begin{array}{c}14 \mathrm{ml}(+) \\
(20 \mathrm{ml})\end{array}$ & $\begin{array}{c}16 \mathrm{ml} \mathrm{(+)} \\
(20 \mathrm{ml})\end{array}$ & $\begin{array}{c}15 \mathrm{ml}(+) \\
(20 \mathrm{ml})\end{array}$ \\
\hline Emulsion Stability & $\mathrm{Oh}$ & $\begin{array}{l}\text { CE (+) } \\
(\text { IEC) }\end{array}$ & $\begin{array}{l}\text { CE }(+) \\
(\text { IEC) }\end{array}$ & $\begin{array}{l}\text { CE }(+) \\
(\text { IEC) }\end{array}$ & $\begin{array}{l}\text { CE }(+) \\
(\text { IEC) }\end{array}$ \\
\hline & $0.5 \mathrm{~h}$ & $\begin{array}{c}\text { MC } 2.5 \mathrm{ml} \\
(+) \\
(5 \mathrm{ml})\end{array}$ & $\begin{array}{c}\text { MC } 3.2 \mathrm{ml} \\
(+) \\
(5 \mathrm{ml})\end{array}$ & $\begin{array}{c}\text { MC } 2.9 \mathrm{ml} \\
(-) \\
(5 \mathrm{ml})\end{array}$ & $\begin{array}{c}\text { MC } 2.7 \mathrm{ml} \\
(-) \\
(5 \mathrm{ml})\end{array}$ \\
\hline & $2.0 \mathrm{~h}$ & $\begin{array}{c}\text { MC } 7.0 \mathrm{ml} \\
(+) \\
(10 \mathrm{ml})\end{array}$ & $\begin{array}{c}\text { MC } 6.5 \mathrm{ml} \\
(+) \\
(10 \mathrm{ml})\end{array}$ & $\begin{array}{c}\text { MC } 8.3 \mathrm{ml} \\
(+) \\
(10 \mathrm{ml})\end{array}$ & $\begin{array}{c}\text { MC } 7.3 \mathrm{ml} \\
(+) \\
(10 \mathrm{ml})\end{array}$ \\
\hline Free Oil & $2.0 \mathrm{~h}$ & $\begin{array}{c}0.9 \mathrm{ml} \\
(-) \\
\text { (Trace) }\end{array}$ & $\begin{array}{c}0.7 \mathrm{ml} \\
(-) \\
\text { (Trace) }\end{array}$ & $\begin{array}{c}1.2 \\
(-) \\
\text { (Trace) }\end{array}$ & $\begin{array}{c}1.7 \\
(-) \\
\text { (Trace) }\end{array}$ \\
\hline Re- Emulsification & $24 \mathrm{~h}$ & $\begin{array}{l}\mathrm{CE}(+) \\
(\mathrm{CRE})\end{array}$ & $\begin{array}{l}\text { CE }(+) \\
\text { (CRE) }\end{array}$ & $\begin{array}{l}\mathrm{CE}(+) \\
(\mathrm{CRE})\end{array}$ & $\begin{array}{l}\mathrm{CE}(+) \\
(\mathrm{CRE})\end{array}$ \\
\hline & $24.5 \mathrm{~h}$ & $\begin{array}{c}\text { MC } 10.6 \mathrm{ml} \\
(+) \\
(20 \mathrm{ml})\end{array}$ & $\begin{array}{c}\text { MC } 12.5 \mathrm{ml} \\
(+) \\
(20 \mathrm{ml})\end{array}$ & $\begin{array}{c}\text { MC } 14.2 \mathrm{ml} \\
(+) \\
(20 \mathrm{ml})\end{array}$ & $\begin{array}{c}\text { MC } 15.1 \mathrm{ml} \\
(+) \\
(20 \mathrm{ml})\end{array}$ \\
\hline Free oil & $24.5 \mathrm{~h}$ & $\begin{array}{c}2.7 \mathrm{ml} \\
(-) \\
\text { (Trace) }\end{array}$ & $\begin{array}{c}3.9 \mathrm{ml} \\
(-) \\
\text { (Trace) }\end{array}$ & $\begin{array}{c}5.2 \mathrm{ml} \\
(-) \\
\text { (Trace) }\end{array}$ & $\begin{array}{c}4.6 \mathrm{ml} \\
(-) \\
\text { ( Trace) }\end{array}$ \\
\hline
\end{tabular}

(+) means Valid ‘(-) means Not Valid,

Where: Valid means (Tested value < maximum limit). Not valid means (Tested value> maximum limit) ، Note: tests after $24 \mathrm{~h}$ are required only where the results at $2 \mathrm{~h}$ are in doubt 
Table 6. Suspensibility \% of the tested WP formulations

\begin{tabular}{|c|c|c|c|c|}
\hline \multicolumn{2}{|c|}{ Pesticide } & \multirow{2}{*}{$\begin{array}{c}\text { Initial weight } \\
\text { of formulation } \\
(\mathrm{gm})\end{array}$} & \multirow{2}{*}{$\begin{array}{c}\text { Weight of } \\
\text { formulation } \\
\text { retained in } 1 / 10\end{array}$} & \multirow{2}{*}{$\begin{array}{c}\text { Suspensibility } \\
\%\end{array}$} \\
\hline Trade names & Active ingredient & & & \\
\hline Agerin $6.5 \%$ WP & (Bacillus thuringiensis) & 20 & 8.6 & $\begin{array}{c}\text { 63.33 Not Valid } \\
(-) \\
(\mathrm{ML}=90 \%)\end{array}$ \\
\hline Anadol $80 \%$ WP & (mancozeb) & 20 & 11.6 & $\begin{array}{c}46.66 \text { Not Valid } \\
(-) \\
(\mathrm{ML}=50 \%)\end{array}$ \\
\hline $\begin{array}{l}\text { Dicozeb } \\
80 \% \text { WP }\end{array}$ & (mancozeb) & 20 & 9.6 & $\begin{array}{c}\begin{array}{c}57.77 \text { Valid } \\
(+) \\
(\mathrm{ML}=50 \%)\end{array}\end{array}$ \\
\hline Dikathrin 5\% WP & (deltamethrin) & 20 & 4.6 & $\begin{array}{c}85.55 \text { Valid } \\
(+) \\
(\mathrm{ML}=60 \%)\end{array}$ \\
\hline $\begin{array}{l}\text { Dipel } 2 \text { X } 6.4 \% \\
\text { WP }\end{array}$ & $\begin{array}{l}\text { (Bacillus thuringiensis } \\
\text { sub sp.kurstaki) }\end{array}$ & 20 & 5 & $\begin{array}{c}83.25 \% \text { Not Valid } \\
(-) \\
(\mathrm{ML}=90 \%)\end{array}$ \\
\hline Difix $25 \%$ WP & (diflubenzuron) & 20 & 3.5 & $\begin{array}{c}91.66 \% \text { Valid } \\
(+) \\
(\mathrm{ML}=60 \%)\end{array}$ \\
\hline Hesta $70 \%$ WP & (thiophanate- methyl) & 20 & 10 & $\begin{array}{c}55.55 \% \text { Not Valid } \\
(-) \\
(\mathrm{ML}=) 60 \%\end{array}$ \\
\hline $\begin{array}{l}\text { Kemazed } \\
50 \% \text { WP }\end{array}$ & (carbendazim) & 20 & 5.7 & $\begin{array}{c}79.44 \%(\text { Valid }+) \\
\quad(\mathrm{ML}=60 \%)\end{array}$ \\
\hline $\begin{array}{l}\text { No- Blight } \\
50 \% \text { WP }\end{array}$ & (thiram) & 20 & 6 & $\begin{array}{c}77.77 \% \text { Valid } \\
(+) \\
(\mathrm{ML}=75 \%)\end{array}$ \\
\hline Pendazin 50\%WP & (carbendazim) & 20 & 7.4 & $\begin{array}{c}69.99 \% \text { Valid } \\
(+) \\
(\mathrm{ML}=60 \%)\end{array}$ \\
\hline $\begin{array}{l}\text { Protecto } \\
9.4 \% \text { WP }\end{array}$ & $\begin{array}{l}\text { (Bacillus thuringiensis } \\
\text { Kurstaki) }\end{array}$ & 20 & 10.8 & $\begin{array}{c}51.11 \% \text { Not Valid } \\
(-) \\
(\mathrm{ML}=90 \%)\end{array}$ \\
\hline
\end{tabular}

ML: Minimum Limit, (+) means Valid, (-) means Not Valid Where: Valid means (Tested value $<$ minimum limit). Not valid means (Tested value $>$ minimum limit).

procedures of legislations on pesticide formulations traded in the markets, and to activate all procedures for checking the quality of products, especially with regard to the implementation of internal quality control systems in plants engaged in the synthetic and pesticide formulations. Cooperation of the responsible body with the management of pesticide facilities is a must in order to advance and develop the National industry and to ensure products that are good enough to complete in foreign markets.

\section{REFERENCES}

Alnuwbaa, E. 2016. Agriculture: The volume of adulterated pesticides in Egypt declined to 14\%. Alyoum 7 news, avaliable at: http://www.youm7.com/story/2016/9/19/

Collaborative International Pesticide Analytical Council, Itd (CIPAC) 2003. Handbook K, "MT 186 Bulk Density” CIPAC, (2003). www.cipac.org

Dinham, B. 2007. Pesticide users at risk. Pesticides News. 77, 10-11. 

pesticide samples traded in Egyptian markets

El-Zemaity, M.S. 2002. Analysis Study of Pesticides Handled in the Saudi Market. Arab Univ. J. Agric Sci., Ain Shams Univ., Cairo, Egypt, 10(2), 453-472.

El-Zemaity, M.S and Mohamed, H.H. 2005. Containers conditions, label information and physicchemical properties of some obsolete pesticides in Egypt during 2000-2002. J. of Environ. Sci., 11(2), 177-194.

FAO/WHO 2014. International Code of Conduct on Pesticide Management.

http://www.fao.org/fileadmin/templates/agphom e/documents/Pests_Pesticides/Code/CODE_2 014 Sep_ENG

FAO/WHO 2011. Food and Agriculture Organization of the United Nations \& World Health Organization. Guidelines for quality control of pesticides. http://whqlibdoc. who.int/hq/2011/WHO HTM_NTD_WHOPES_2011.4_eng. Rome \& Geneva: Food and Agriculture Organization of the United Nations \& World Health Organization.

FAO/ WHO 2002. International Code of Conduct on the Distribution and Use of Pesticides, FAO, Rome, pp. 365 -375.

Hamid, M. 2016. The size of the fake pesticide trade is close to $\$ 2$ billion worldwide. Alnabaa net, available in: http://www.alnabaa.net/614569

JMPS. 2010. Manual on development and use of FAO and WHO specifications for pesticides. FAO/WHO, Rome, pp. 211-222.

Legislative Counsel Committee 2016 a. Chapter 634-Pesticide Control, https://www.oregonlegislature.gov/bills_laws/ors/ors634.html (2015) (last accessed Jul. 16, 2016).
Legislative Counsel Committee 2016b. Annotations to the Oregon Revised Statutes, Cumulative Supplement - 2015, Chapter 634, https://www.oregonlegislature.gov/bills_laws/ors/ano634.html (2015) (last accessed Jul. 16, 2016).

Malkov, M., Prischepa, S. and Kutonova, T. 2015. Counteraction to Counterfeit and Contraband Pesticides - Methodology. Organization for Security and Co-operation in Europe (OSCE) within the Environment and Security Initiative (ENVSEC), 350 p.

Matthews, G., Tan, SH., van der Valk, H., Ameneshewa, B. and Mnzava, A. 2010. Problems confronting management of public health pesticides. Inte. Pest Control 52, 250-254.

Rizk, G.A. 2006. Strategies of Plant Protection, Present and Future Prospects. In: Proceeding of the First Conference of Agricultural Pesticides Committee. APC/6/2006. pp. 111-115.

Rother, H.A. 2010. Falling through the regulatory cracks: street selling of pesticides and poisoning among urban youth in South Africa. Int. J. Occup. Environ. Health 16, 202-213.

Salem, Amira 2016. "Agriculture": The size of adulterated pesticides in Egypt is less than the world rate. Albawabh news, available in:www.albawabhnews.com/2229167. 23 p.

WHO 2015. WHO Pesticide Evaluation Scheme: WHOPES. http://www.who.int/whopes/. Geneva: World Health Organization. 12 p. 